\title{
Vulnerability Evaluation of Groundwater of N’Djamena City: Contribution of the Parametric Methods GOD and SI
}

\author{
David Deubalbe1, Edith Kadjangaba1,2, Djimako Bongo ${ }^{3}$, Sabine Djimouko4, \\ Jean Claude Doumnang Mbaigane ${ }^{1}$, Yaya Mahmout ${ }^{5}$ \\ ${ }^{1}$ Geology Department, Faculty of Exact and Applied Sciences, University of N'djamena, N'djamena, Chad \\ ${ }^{2}$ Faculty of Sciences and Techniques, University of Doba, Doba, Chad \\ ${ }^{3}$ Higher Normal School of Technology of Sarh, Sarh, Chad \\ ${ }^{4}$ Letters, Arts and Human Sciences Faculty, University of Moundou, Moundou, Chad \\ ${ }^{5}$ Natural Substances Laboratory, Exact and Applied Sciences Faculty, University of N’Djamena, N’Djamena, Chad \\ Email: edith.kadjangaba@gmail.com,djimako.b5@gmail.com
}

How to cite this paper: Deubalbe, D., Kadjangaba, E., Bongo, D., Djimouko, S., Mbaigane, J.C.D. and Mahmout, Y. (2021) Vulnerability Evaluation of Groundwater of N'Djamena City: Contribution of the Parametric Methods GOD and SI. Journal of Environmental Protection, 12, 472-489. https://doi.org/10.4236/jep.2021.127030

Received: May 28, 2021

Accepted: July 12, 2021

Published: July 15, 2021

Copyright $\odot 2021$ by author(s) and Scientific Research Publishing Inc. This work is licensed under the Creative Commons Attribution International License (CC BY 4.0).

http://creativecommons.org/licenses/by/4.0/

(c) (i) Open Access

\begin{abstract}
The purpose of this work is to study the vulnerability of the Quaternary aquifer that lies beneath the N'Djamena city Chad. The subsoil of N'Djamena city Chad is made up of a multilayered aquifer in which there are two main aquifers located respectively at a depth of about 10 and $60 \mathrm{~m}$, between the two there is an intermediate aquifer at about $30 \mathrm{~m}$ depth. It is this latter water table, generally captured by human-powered pumps, that is the subject of this study. Because of anarchic garbage dumping, wastewater discharge, latrines scattered throughout the city, chemical fertilizers and herbicides used on the banks of Chari River and its tributary the Logone for market gardening, the quality of the water in this aquifer is highly threatened. Moreover, it has been noting that the sources of pollution are constantly increasing in conjunction with the growth of the population, so the knowledge and protection of groundwater are necessary. We have therefore carried out a study of intrinsic vulnerability using two mapping methods (GOD and SI), as mapping is recognized as an effective tool for decision support in the case of safeguarding water resources. The results obtained by the GOD method show that $38 \%$ of the study area is covered by high vulnerability, $29 \%$ by moderate vulnerability, $21 \%$ by low vulnerability and $21 \%$ by the very low vulnerability. With the SI method, $54 \%$ of the study area is covering by low vulnerability and $46 \%$ by the low and moderate vulnerability. The coincidence rate of low nitrate values in groundwater with areas of very low and low vulnerability is $91 \%$ and $76 \%$ for the GOD and SI methods, respectively. Although these observations validated the dif-
\end{abstract}


ferent maps obtained, the SI approach seems to be the most adequate for vulnerability tracing in our study area.

\section{Keywords}

Vulnerability, GOD, SI, Groundwater, Nitrate, N’Djamena City

\section{Introduction}

Water is necessary for all life on planet and is a factor in promoting the health of individuals and the socio-economic development of human communities [1]. Groundwater, which represents a total of about $97 \%$ of liquid continental freshwater [2], is increasingly exploited for drinking water supply (DWR). This is reflected in the renewed interest in human-powered boreholes observed in recent times in Sub-Saharan African countries.

Groundwater is not immune to surface pollution since it is largely renewed by rainwater that falls on the surface before infiltrating through the soil to the water table, carrying with it certain undesirable products. However, natural groundwater is generally free of contamination, especially when it is deep, because of the purifying power of soil; but in recent decades, there has been an increased degradation of this resource.

The process of water degradation, although very slow, can have serious effects [3], especially on human health. The increasing pollution of the groundwater leads to the alteration of the quality and the decrease of the quantity of drinking water. This is very worrying because, in the long term, water resources will be weakened even if they are renewable. This pollution is the consequence of the galloping demography and the intensity of uncontrolled anthropic activities in the urban environment. Scientists have developed the concept of vulnerability to the pollution of aquifers in order to find a solution to the increasing deterioration of water resources. Knowing that in a given region, the vulnerability of aquifers to pollution results from the interaction of several factors, among which we can enumerate the hydrogeology, the aquifer-contaminant reaction and the sources of pollution [4].

In N'Djaména city Chad, groundwater contamination is essential of anthropogenic origin [5] [6] [7] [8]: it is reflected in the high presence of nitrate levels in the water resulting from the discharge of wastewater, industrial effluents, unauthorized dumping of garbage, latrines, dilapidated sewage systems or animal excrement.

The decontamination of water is not always easy, because it requires large financial means, which is not always within the reach of developing countries and especially Chad. In view of this, it is necessary that measures be taken to know and protect the groundwater of the N'Djamena city Chad.

In this context, measures to help protect and prevent groundwater pollution become an important step towards which many efforts must be provided. Among 
these measures, the mapping of areas vulnerable to pollution [9] is a decisive tool for decision support. This is widely used for groundwater protection and decision-making in the case of land use planning [10] [11] and water development projects. Vulnerability maps identify the different degrees of sensitivity of the aquifer [12] and the identification of areas of high vulnerability can prevent some of the contamination.

There are many methods for estimating groundwater vulnerability, and these are broadly dividing into three groups [13] [14]. These include statistical methods, simulation models and index mapping methods.

In the case of this study, we chose the parametric index mapping methods GOD and SI. The GOD method was developing by [15] to assess the intrinsic vulnerability of the aquifer to pollutants while the SI or DRATOS method was developing in Portugal by [16] to take into account the behavior of pollutants of agricultural origin such as nitrates.

The aim of this work is to study the vulnerability of the Quaternary aquifer under N'Djamena city Chad, using the GOD and SI parametric methods. The highlighting of nitrate mapping, which is an indicator of anthropogenic pollution, is part of the validation process of vulnerability maps. The parameter "land use" of the SI method allows taking into account the risks linked to anthropic actions likely to generate groundwater pollution and contaminant aquifers of Ndjamena Chad.

\section{Materials and Methods}

\subsection{Presentation of Area Study}

N'Djamena, capital of Chad, is the largest city in country. It was creating on April 22, 1900 and established as a commune in 1919. Geographically, N'Djamena city Chad (study area) is located in western Chad on the border with Cameroon between $12^{\circ} 06^{\prime} 59^{\prime \prime}$ North and $15^{\circ} 04^{\prime} 20^{\prime \prime}$ East. N'Djamena city Chad has a population of about 1,500,000 (INSEED, 2017) with an annual growth rate of about 7\% and a density of about 83 inhabitants/ha according to the 2013 National Symposium report. The city is located on a relatively flat area with an average elevation ranging from 280 to 320 meters (Figure 1) with relatively low natural slopes ranging from $1 \%$ to $2.5 \%$ and today covers an urbanized area of 40,000 hectares (ha). Administratively, Ndjamena city Chad is dividing into ten (10) administrative units called Municipal Districts and subdivided into 78 neighborhoods, 1650 squares. These represent the smallest administrative units in the city (Table 1).

According to the literature [17] [18], the hydrographic network is essentially composed of the Chari River, the most important river in Chad, which has its source in Mount Yadé (in the Central African Republic). Its main tributary, the Logone, at the town, joins it. The latter originates in the Adamaoua massif in Cameroon. Throughout the N'Djamena city Chad (Figure 1), there are depressions that correspond to quarries dug for the construction of houses. During the rainy season, rainwater and runoff accumulate in these depressions; they stagnate 


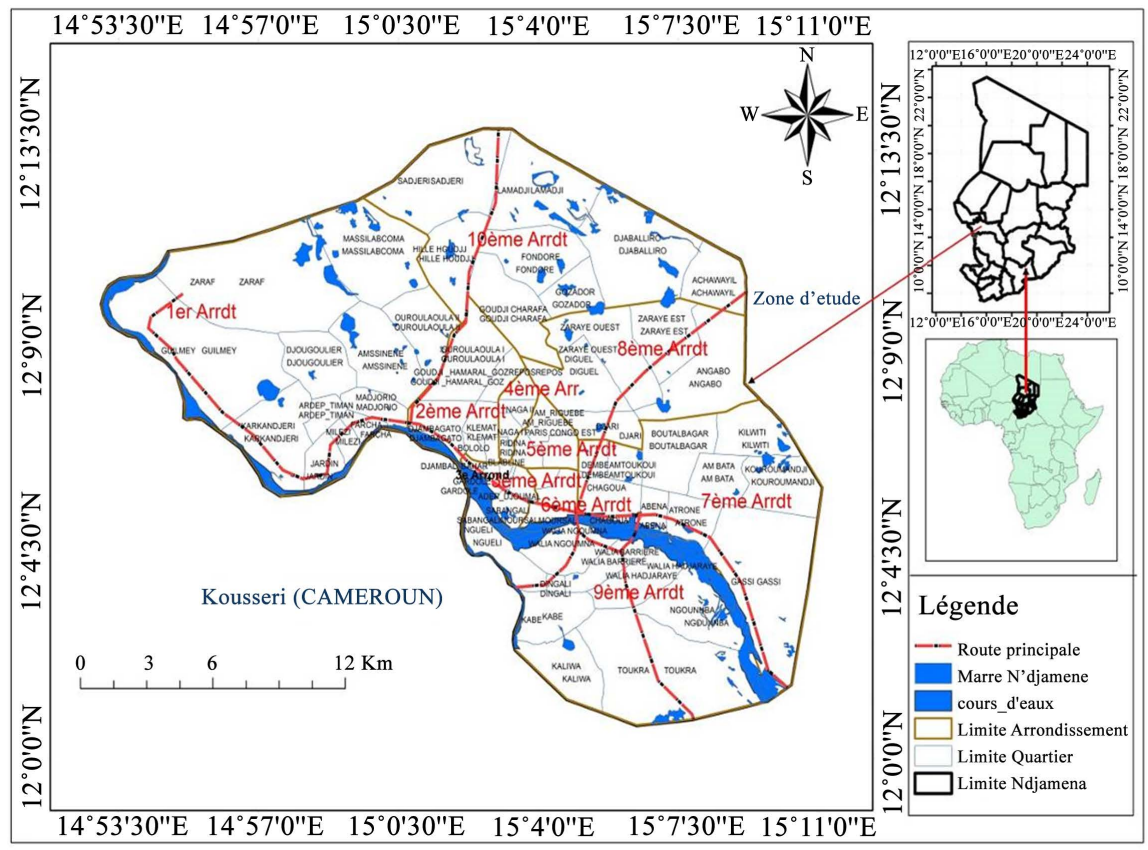

Figure 1. Location map of area study.

Table 1. Criteria for estimating GOD vulnerability ([25] [30]).

\begin{tabular}{cc}
\hline Vulnerability class GOD & vulnerability index \\
\hline Very low vulnerability & $0-0.1$ \\
Low vulnerability & $0.1-0.3$ \\
Moderate vulnerability & $0.3-0.5$ \\
High vulnerability & $0.5-0.7$ \\
Extreme vulnerability & $0.7-1$ \\
\hline
\end{tabular}

there throughout the wet season before dissipating either by evaporation or infiltration, or by the combined effect of the two phenomena, thus giving rise to more or less permanent pools depending on their size. There is also the presence of a large canal that crosses the city from north to south and whose purpose is to drain wastewater.

The subsoil of N'Djamena city Chad contains two superimposed aquifer levels [19] [20] [21] [22]. These are separating by an impermeable to semi-permeable clay level in places; these two aquifers are rather part of the same whole. In addition, the [23] also reports locally, the presence of intermediate aquifers at a depth of 20 to $30 \mathrm{~m}$. These aquifers are fed mainly by the Chari River and sometimes by rainwater [5] [7].

\subsection{Materials, Data Collection and Processing}

The data and information collected for this study came from several sources. The Water Chadian Society (STE), the Centre of Geographic Documentation (CDG) of the Ministry in charge of Environment, Water and Fisheries and vari- 
ous drilling companies, provided them to us. The different data collected concern the drilling depths, lithological sections and pumping tests. The piezometric data comes from fieldwork conducted in March 2018 as part of this study and supplemented by those of the town hall conducted during the same year (N'djamena Town Hall, 2018).

The results of nitrate analyses were obtaining from the database of the $\mathrm{Na}$ tional laboratory of water (LNE). From the Lansat 8 image of N'Djaména city Chad obtained from the National center for the reseach and development (CNRD) in 2017. We were able to generate with ArcGIS version 10.4 software the drainage flow map of the hydrographic network, the depth map of the aquifers, the recharge map, the type of aquifer, or the piezometric level as well as the topographic map.

The information on the land use of N'Djamena Chad plain comes from the land use database of the Agriculture Ministry and more precisely from the service in charge of the Information System for Rural Development and Land Use (SIDRAT) collected in 2016. Various software programs were using to process all these data and Surfer was using for the processing and spatial analysis of the data. The land use map (OS) was obtaining from the processing and classification of the Lansat 8 image of SIDRAT following the SI weights [16]. These weights are ratings assigned by class for the Land Use (LU) values assigned to each of the parameters according to its relative influence on vulnerability [16]

\section{Method}

\subsection{GOD Method: Parameters and Ratings}

The GOD method was developing by [15] to assess the intrinsic vulnerability of aquifer pollution. It presents the vulnerability of the aquifer, to vertical percolation of pollutants through the unsaturated zone and does not address the lateral migration of pollutants into the saturated zone. In the GOD method, the role of the soil in protecting the aquifer is neglected [15]. This method is based on the combination of three hydrogeological parameters: Groundwater occurrence, overall aquifer class and Depth to groundwater table. The estimation of these parameters is easy, as it is based on the information collected by the operators) even on a drilling $\log$ [24]. This method allows for a quick estimate of vulnerability [25]. The GOD index (IGOD) that allows evaluating the vulnerability is obtained by multiplying these three parameters according to Equation (1) [25] below:

$$
\mathrm{IGOD}=\mathrm{Gi} * \mathrm{Op} * \mathrm{Da}
$$

$\mathrm{Gi}, \mathrm{Op}$, and $\mathrm{Da}$ represent the index values of aquifer type $(\mathrm{G})$, water table depth $(\mathrm{O})$, and aquifer unsaturated zone layer lithology or geologic features $(\mathrm{D})$, respectively. The value of the GOD index varies between 0 and 1 (Table 1). Furthermore, the closer to the value of 1 , the more pollution potential is raised.

The different ranges of GOD index obtained are relating to the vulnerability classes (Table 1). In general, the obtained GOD indices are dividing into five (5) 
ranges of vulnerability classes ranging from "very low" to "extreme" vulnerability.

\subsection{SI or Drastos Method, Parameters and Scoring}

The SI (Susceptibility Index) method was developing in Portugal by [16]. It is a specific vertical vulnerability method, developed to take into account the behavior pollutants of agricultural origin (organic), mainly nitrates.

SI is a derived version of the DRASTIC model developed by [26], and is known as DRATOS [27].

In the vulnerability assessment process, the DRATOS model considers five parameters. The first four parameters are similar to the four parameters used in the DRASTIC method (D: depth to water table, R: effective aquifer recharge, A: aquifer lithology, and T: topography). Therefore, the ratings corresponding to the different classes of parameters used in the DRASTIC method are the same as those used by the SI method. In addition to the common parameters, the land use (OS) parameter is added, which takes into account the impact of anthropogenic activities [28].

The land cover (OS) parameter was obtaining by processing the Landsat image SIDRAT Database, 2016.

For this parameter, we used the [29] classification as represented in Table 2. To each land cover class corresponds a value called land cover factor noted LU, the latter varies from 0 to 100 thus going from least vulnerable to most vulnerable. Thus, the minimum value 0 corresponds to forests and semi.

The maximum value of 100 is assigned to industrial landfills, garbage dumps and mines.

The weights assigned to the SI parameters vary from 0 to 1 depending on the importance of the parameter in the vulnerability (Table 3). The Vulnerability

Table 2. Main land covering classes and LU values [16]. Land use classification according to $[29]$.

\begin{tabular}{cc}
\hline \multicolumn{2}{c}{ Parameter: Land Use and corresponding Land Use (LU) values } \\
\hline Land use class (OS) & LU factor value \\
\hline Industrial landfill, garbage dump, mines & 100 \\
Quarry, shipyard & 90 \\
Irrigated perimeter, rice fields, irrigated and non-irrigated annual crops & 80 \\
Covered artificial areas, green areas, continuous urban areas & 75 \\
Permanent crops (vines, yards, olive trees, etc.) & 70 \\
Discontinuous urban areas & 70 \\
Pastures and agro-forestry areas & 50 \\
Aquatic environments (tides, salt flats, etc.) & 50 \\
Forest and semi-natural areas & 0
\end{tabular}


Index (VI) is calculating by summing the products of the scores by the weights of the corresponding parameters, as summarized by the formula below:

$$
\begin{aligned}
& \text { ISI ou IDRATROS } \\
& =0.186 * \mathrm{D}+0.212 * \mathrm{R}+0.259 * \mathrm{~A}+0.121 * \mathrm{~T}+0.222 * \mathrm{OS}
\end{aligned}
$$

This method presents four degrees of vulnerability according to the index values obtained (Table 4).

Apart from the two models, we used the ArcGIS software developed by ESRI. This Geographic Information System (GIS) software, equipped with powerful mathematical functions and tools, allowed us to work both in vector, raster and raster systems. The most used tools on ArcGIS are the "Interpolate IDW" module for the analysis and spatialization of point data, the "Reclassify" module for the attribution of coasts and the "Map calculator" module for the cross-referencing operations between the different thematic maps. The comparative flowchart of the realization of the vulnerability map from the GOD and SI methods is shown in Figure 2.

Table 3. Weights assigned to SI or DRATOS parameters (ranging from 0 to 1 , from least to most important) [16] [27].

\begin{tabular}{cccccc}
\hline Parameter & D & R & A & T & OS \\
\hline Weight & 0.186 & 0.212 & 0.259 & 0.121 & 0.222 \\
\hline
\end{tabular}

Table 4. SI vulnerability assessment class [16] [27].

\begin{tabular}{cc}
\hline Degree of vulnerability & Vulnerability index \\
Low & $<45$ \\
Moderate & $45-64$ \\
High & $65-84$ \\
Very high & $85-100$ \\
\hline
\end{tabular}

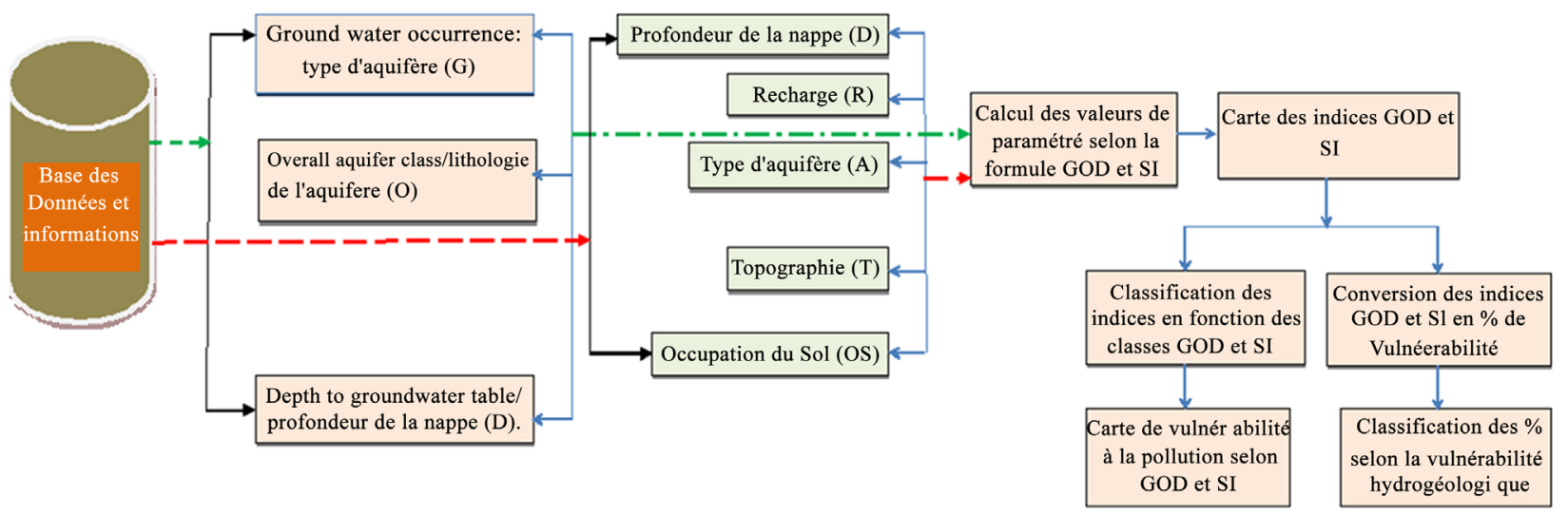

Figure 2. Summary flowchart of the GIS applied to the GOD method and SI of the study. 


\section{Results}

The GOD vulnerability map (Figure 3 ) and the SI vulnerability map (Figure 4) were obtained by raster calculation on the ArcGIS environment, respectively by weighting and combining the different parametric maps of each method.

Several hydrogeological parameters such as aquifer type, effective recharge, depth and lithology of the aquifer were mapped by the process of interpolation (spatial analysis) of the technical data of the boreholes on ArcGIS. As for the vulnerability maps, they are produced by raster calculation applied to the vulnerability index formula GOD [15] and SI [16]. Note that the reliability of the interpolation depends mainly on the quality of the data used for the realization of the maps and on the homogeneous and representative distribution of the measurement points [28]. On the other hand, the physical parameter such as "slope and land use (OS)" was obtaining by processing the Landsat 8 image (SIDRAT database). These Landsat images were using to establish a thematic classification for land cover and a classification of slope indices according to the SI method.

\subsection{Level of Vulnerability of N'Djamena Water Table According to GOD}

Five vulnerability index ranges were identified by the GOD method, with vulnerability index values ranging from 0.126 to 0.657 . The analysis of these index ranges gives four classes of vulnerability to pollution (Figure 3):

$>$ The class of very low vulnerability, which is located in the northern and eastern part of the study area, it occupies the smallest proportion because it represents only $13 \%$ of the area. This class is explaining by the presence of layers with clay dominance. The static levels in this area are generally between 15 and $17 \mathrm{~m}$.

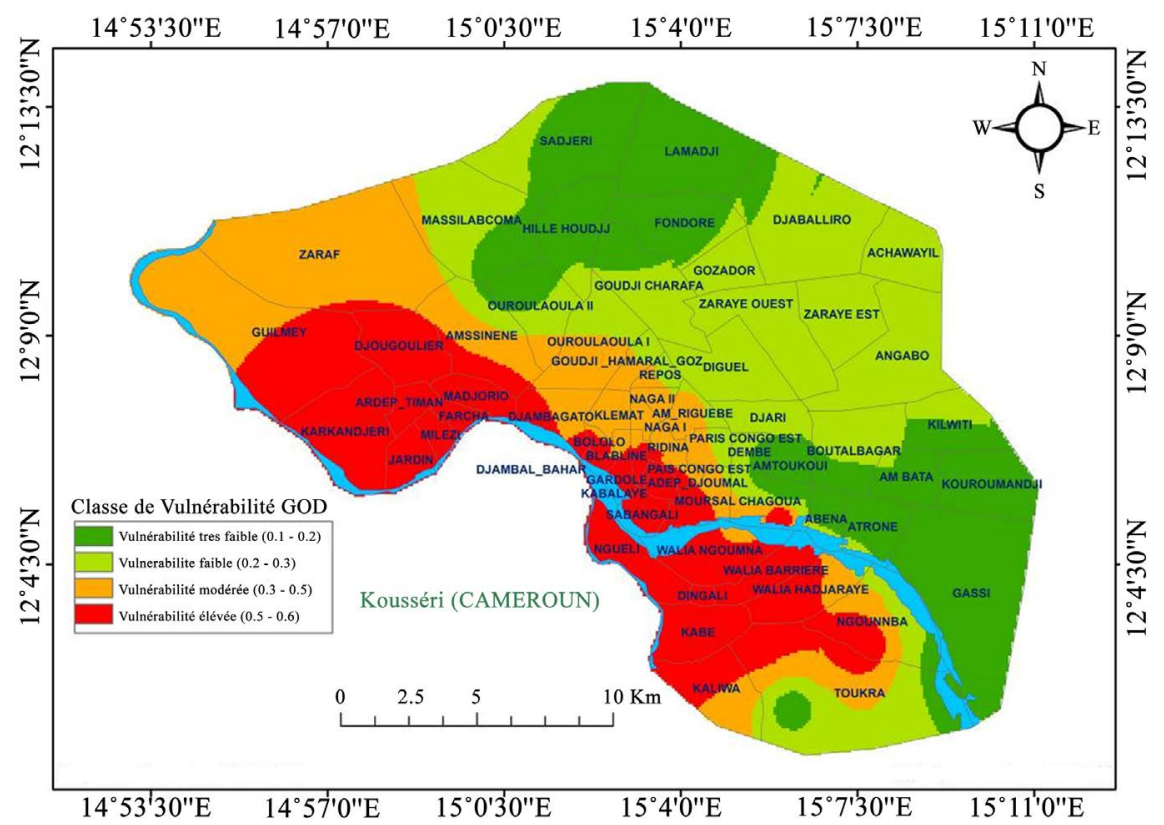

Figure 3. GOD model vulnerability map. 


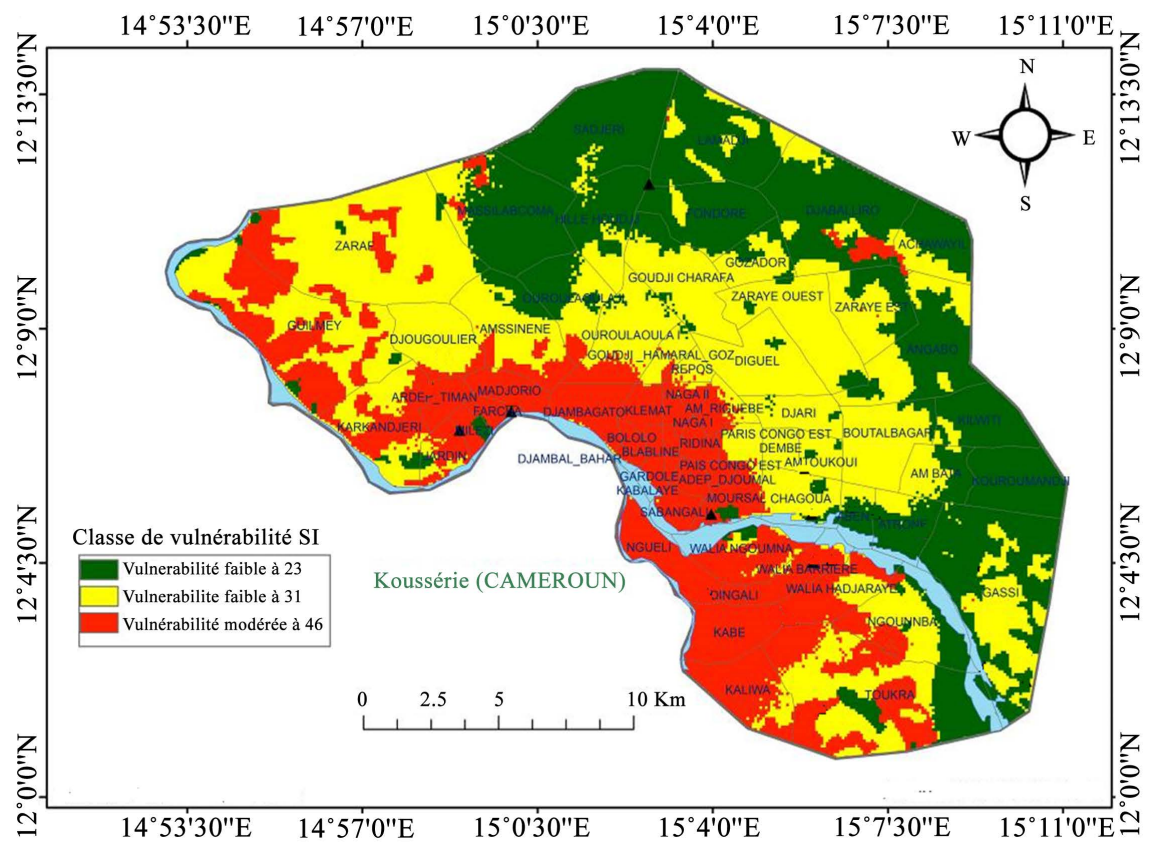

Figure 4. SI or DRATOS model vulnerability map.

The class of low vulnerability is located in the northern and northeastern part of the study area where it represents $20 \%$ of the area of the study area. This is the intermediate vulnerability between the very low vulnerability class and the moderate vulnerability class. The static levels in this zone are generally between 13 and $14 \mathrm{~m}$.

$>$ The moderate vulnerability class occurs in the center and west along a strip and in the southern part of the study area. It represents $27 \%$ of the total area. In this area the static level is approximately between 11 and $12.5 \mathrm{~m}$.

$>$ This moderate degree of vulnerability can be explaining by the nature of the unsaturated zone made up of silty sand that is not very permeable to infiltration, to which is added the occupation of the land by housing. These conditions, favor the infiltration of contaminants and make these sectors sensitive to pollution, they must therefore be monitored.

> The high vulnerability class occurs in a band along the southern part of the study area. This class occupies relatively all of the areas along the Chari and Logone rivers (Sabangali, Farcha, Melezi, Ngueli, Walia, Ndigangali, Ngomba) and represents about $40 \%$, or a little more than a third of the study area. The high degree of vulnerability can be explaining by the litho-stratigraphic context of the unsaturated zone dominated by sands. Static levels in this zone are generally between 8 and $10 \mathrm{~m}$.

\subsection{Level Vulnerability of N'Djamena Water Table According to SI}

The SI method allowed us to obtain 5 classes of vulnerability indexes for our area study varying between 4.01 (minimum value) and 45.72 (maximum value). These indices were dividing into two classes of vulnerability pollution (Figure 4):

$>$ Low vulnerability class represents $54 \%$ and occupies for most part the north- 
ern end and center of the plain of area study. This less severe vulnerability class may be relating to the nature of the unsaturated zone made up of clay, which is not very permeable and which could probably act as a purifier for pollutants.

Moderate vulnerability class occurs in a strip along the southern part, is distributing almost all along the banks of Chari and Logone rivers, and extends towards the center of total area study; it is also found in blocks in northern part of area study. This class represents $46 \%$ of area. The areas affected by moderate and specific vulnerability contain mainly crop perimeters, swamp gardens or forest areas. The moderate degree of vulnerability of these areas can be explained by the fact that these areas are possibly marked by the use pollutants (fertilizer, herbicide), and they are constituted of sands and silts which are very permeable because of their porosity. In these areas of moderate vulnerability, there are also areas where the sewage system is defective, areas previously filled with garbage before the construction of houses.

\subsection{Validation of Vulnerability Map}

In order to test and validate pollution vulnerability map, many authors [27] [30] [31] [32] [33] [34] have relied on groundwater chemical data. This consists in making a comparison between the distribution of nitrates in the studied groundwater and the distribution of vulnerability classes. In our case, to verify the validity of the vulnerability maps obtained by the GOD and SI methods, we used nitrate levels from a measurement campaign of 34 water points carried out in 2018 across N'djamena city Chad. Nitrate levels in groundwater in N'Djamena city Chad vary from 0 to $150 \mathrm{mg} / \mathrm{L}$ with an average of $8 \mathrm{mg} / \mathrm{l}$ and $70 \%$ of these samples have nitrate levels below $50 \mathrm{mg} / \mathrm{L}$ [35]. We divided the nitrate concentrations into three groups, namely the low $(0-15 \mathrm{mg} / \mathrm{L})$, medium $(15-50 \mathrm{mg} / \mathrm{L})$ and high $(\geq 50 \mathrm{mg} / \mathrm{L})$ nitrate concentration range.

These different levels overlap indifferently with the very low, low, medium and high vulnerability class (Figure 5 and Figure 6).

\subsubsection{For the GOD Map}

On the validity map of vulnerability pollution by GOD method (Figure 5) and Table 5) we see that the thirty-four (34) values between 0 and $15 \mathrm{mg} / \mathrm{L}$ of nitrate, seventeen (17) of these values coincide with the very low vulnerability zone. Fourteen (14) of these values correspond to the low vulnerability zone and three (3) correspond to the high vulnerability zone. The six (6) values between 15 and $50 \mathrm{mg} / \mathrm{L}$ are in the Low Vulnerability Zone and the six (6) values greater than or equal to $50 \mathrm{mg} / \mathrm{L}$ nitrate are also in the Low Vulnerability Zone.

\subsubsection{For the SI Map}

Component heads identify the different components of your paper and are not topically subordinate to each other. On the SI pollution vulnerability validity map (Figure 6) and Table 5, twenty-six (26) values between 0 and $15 \mathrm{mg} / \mathrm{L}$ nitrate coincide with the low vulnerability zone and eight (8) of these values correspond 


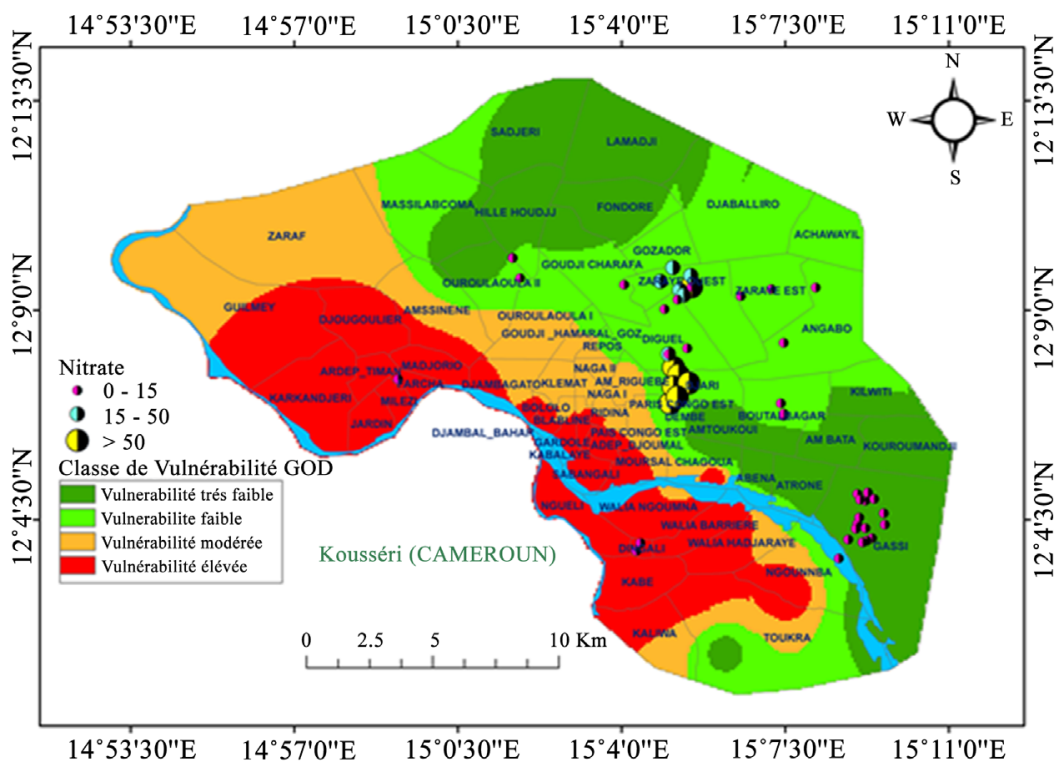

Figure 5. Validity of the nitrate vulnerability map, GOD method.

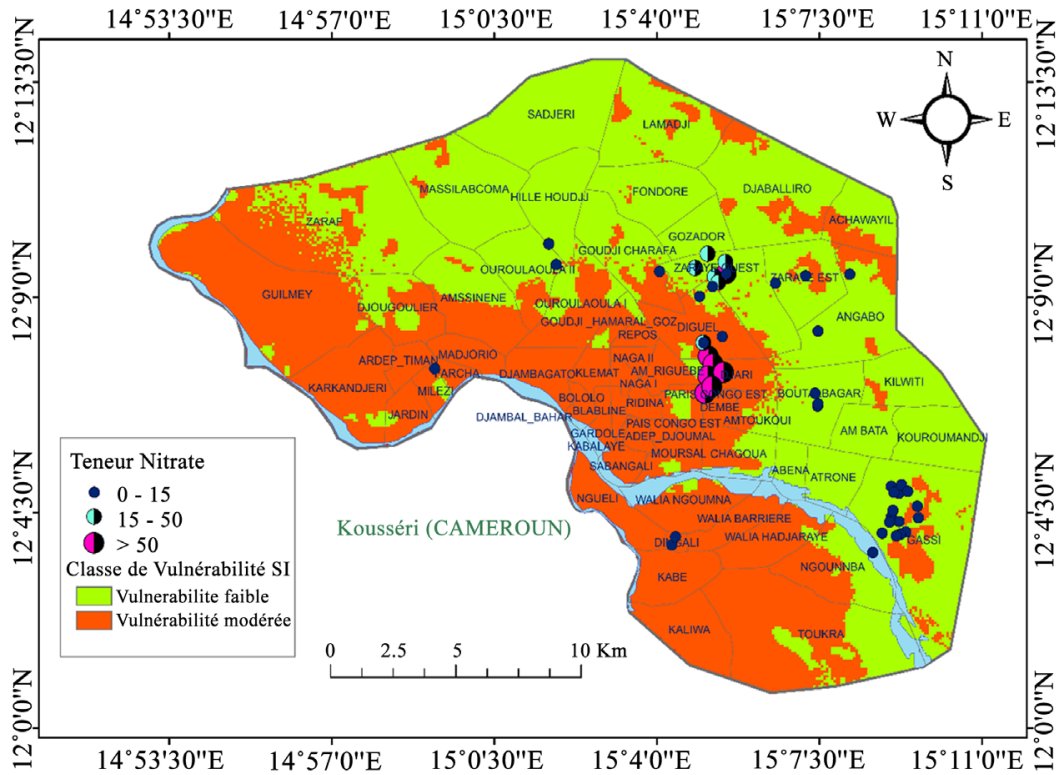

Figure 6. Validity of the nitrate vulnerability map, SI method.

Table 5. Comparison of the map obtained by GOD and SI model with the nitrate concentrations measured in 2018.

\begin{tabular}{|c|c|c|c|c|c|c|c|c|c|c|c|c|c|}
\hline \multirow{3}{*}{$\begin{array}{l}\text { Degrees of } \\
\text { Vulnerability } \\
\text { According } \\
\text { to GOD }\end{array}$} & \multicolumn{6}{|c|}{ Nitrate content } & \multirow{3}{*}{$\begin{array}{c}\text { Degrees of } \\
\text { Vulnerability } \\
\text { According } \\
\text { to GOD }\end{array}$} & \multicolumn{6}{|c|}{ Nitrate content } \\
\hline & \multicolumn{2}{|c|}{$0-15 \mathrm{mg} / \mathrm{L}$} & \multicolumn{2}{|c|}{$15-50 \mathrm{mg} / \mathrm{L}$} & \multicolumn{2}{|c|}{$>50 \mathrm{mg} / \mathrm{L}$} & & \multicolumn{2}{|c|}{$0-15 \mathrm{mg} / \mathrm{L}$} & \multicolumn{2}{|c|}{$15-50 \mathrm{mg} / \mathrm{L}$} & \multicolumn{2}{|c|}{$>50 \mathrm{mg} / \mathrm{L}$} \\
\hline & $\begin{array}{l}\text { Number } \\
\text { of points }\end{array}$ & $\begin{array}{c}\text { Total } \\
\%\end{array}$ & $\begin{array}{l}\text { Number } \\
\text { of points }\end{array}$ & $\begin{array}{c}\text { Total } \\
\%\end{array}$ & $\begin{array}{l}\text { Number } \\
\text { of points }\end{array}$ & $\begin{array}{c}\text { Total } \\
\%\end{array}$ & & $\begin{array}{l}\text { Number } \\
\text { of points }\end{array}$ & $\begin{array}{c}\text { Total } \\
\%\end{array}$ & $\begin{array}{l}\text { Number } \\
\text { of points }\end{array}$ & $\begin{array}{c}\text { Total } \\
\%\end{array}$ & $\begin{array}{l}\text { Number } \\
\text { of points }\end{array}$ & $\begin{array}{c}\text { Total } \\
\%\end{array}$ \\
\hline Very low & 17 & $51 \%$ & & & & & Very low & & & & & & \\
\hline Low & 14 & $41 \%$ & 6 & $100 \%$ & 6 & $100 \%$ & Low & 26 & $76 \%$ & 6 & $100 \%$ & & \\
\hline Moderate & & & & & & & Moderate & 8 & 23.52 & & & & \\
\hline High & 3 & $8.82 \%$ & & & & & High & & & & & 6 & $100 \%$ \\
\hline
\end{tabular}


to the moderate vulnerability zone. Six (6) values between 15 and $50 \mathrm{mg} / \mathrm{L}$ are also in the Low Vulnerability Zone and the six (6) values greater than or equal to $50 \mathrm{mg} / \mathrm{L}$ nitrate are in the Moderate Vulnerability Zone.

\section{Discussions}

Comparing the percentages of surfaces occupied by the different classes of vulnerability according to SI and GOD (Table 6), we note that for the GOD method, the high vulnerability class occupies the highest surface (38\%) followed by the moderate (29\%), low (21\%) and very low (12\%) vulnerability classes. With the SI method, we note the absence of very low and high vulnerability, while we have a fairly balanced distribution between low (54\%) and moderate (46\%) vulnerability.

This observed difference in the number of classes may be relating to the fact that the class boundaries and dimensions that are assigned to different parameters are not absolute. This implies that the standard class boundaries may not reflect the reality on the ground where one class may surround different hydrogeological units [36].

Based on the results obtained from the two (2) methods (GOD and SI), it appears that the GOD method overestimated the vulnerability compared to the SI method (presence of the high vulnerability class). This finding is in agreement with some work done in some sub-Saharan regions such as Burkina [37] or Cameroon [28].

It should be noting that in the realization of vulnerability maps by both SI and GOD methods, we are faced with a number of difficulties. Indeed, one of the difficulties related to the elaboration of parameter maps is the process of interpolation whose reliability depends on the data used for their realization. This interpolation can lead to errors in the realization of parameter maps, because it is only reliable within the intervals delimited by the point data [38]. Another difficulty in applying the GOD and SI method is the class boundaries in terms of index and ratings that are assigning to the different parameters [28]. However, despite these difficulties, we obtained interpretable and satisfactory results that give an overview of the level of pollution in our study area and therefore we were able to identify the areas that need to be monitored closely.

Table 6. Comparison of percentage of area occupied by vulnerability class.

\begin{tabular}{ccc}
\hline \multirow{2}{*}{ Vulnerability Class } & \multicolumn{2}{c}{ Percentage of Area by Class and Method (\%) } \\
\cline { 2 - 3 } & SI or DRATOS (occupied surface) & GOD (occupied surface) \\
\hline Very low & $0 \%$ & $12 \%$ i.e. 4740 ha or $47.4 \mathrm{Km}^{2}$ \\
Low & $54 \%$ or 21,330 ha or $213.3 \mathrm{Km}^{2}$ & $21 \%$ or 8295 ha or $82.95 \mathrm{Km}^{2}$ \\
Moderate & $46 \%$ or 18,170 ha or $181.7 \mathrm{~km}^{2}$ & $29 \%$ or 11,455 ha or $114.55 \mathrm{~km}^{2}$ \\
High & $0 \%$ & $38 \%$ or 15,010 ha or $150.1 \mathrm{Km}^{2}$ \\
\hline
\end{tabular}




\section{Comparison of Maps and Methods (GOD and SI)}

Knowing that our study area is an urban area located in a semi-arid climate, in this context we can consider that the classes of moderate and high vulnerability represent areas threatened by pollution. They cover about $67 \%$ and $46 \%$ for GOD and SI respectively.

The moderate and high vulnerability zones in the central part of the study area correspond to areas where the influence of human activities responsible for increasing anthropogenic pollution has been noted in numerous studies ([5] [6] [8]). In these areas, nitrate levels are very high and can exceed $50 \mathrm{mg} / \mathrm{L}$, which is the acceptable standard for drinking water [35]. These high levels come from latrines, illegal garbage dumps, and sewage discharge.

The vulnerable areas are also found all along the Chari River, this finding was also made by [39] using the DRASTIC method. Their presence may be relating to the type of soil made up of very permeable alluvial deposits present along the river, moreover the water table is not very deep and it represents high recharge zones [7].

It should also be noting that in these vulnerable areas that border the Chari River on both sides, apart from the influence of the above-mentioned sources of pollution, the use of pesticides and fertilizers contributes to the deterioration of groundwater quality. In these areas, the population also cultivates vegetables; therefore, these are areas to be closely monitored.

The very low and low vulnerability class covers about $33 \%$ and $54 \%$ of the area study for GOD and SI respectively. They are generally, found in the northern and northeastern part of area study and are probably relating to the low permeability of the clay-rich unsaturated zone formations and the almost zero recharge rate. Moreover, when moving away from the river towards the north, the water table becomes deeper and deeper and is therefore relatively protected. To validate vulnerability maps, we compared the distribution of nitrates in the groundwater of N'Djamena city Chad with the distribution of vulnerability class.

The nitrate measurement campaign carried out in our area study shows that there are relatively high values of nitrate in both low vulnerability and medium and high vulnerability areas according to the methods (Table 5).

The rate of coincidence between the nitrate levels in the water of the city of N'Djamena Chad and the different class of vulnerability degrees allows us to observe the following.

For GOD method, $91 \%$ of nitrate concentrations below $15 \mathrm{mg} / \mathrm{L}$ are measured in a very low-to-low vulnerability zone and about $9 \%$ in a high vulnerability zone; $100 \%$ of values between 15 and $50 \mathrm{mg} / \mathrm{L}$ are measured in a low vulnerability zone; $100 \%$ of values above $50 \mathrm{mg} / \mathrm{L}$ are also measured in a low vulnerability zone. For SI method, $76 \%$ of the concentrations below $15 \mathrm{mg} / \mathrm{L}$ are measured in a low vulnerability area and about $24 \%$ in a moderate vulnerability area, $100 \%$ of the values between 15 and $50 \mathrm{mg} / \mathrm{L}$ in a low vulnerability area; $100 \%$ of the values above $50 \mathrm{mg} / \mathrm{L}$ in a high vulnerability area.

In both cases, we note on the one hand a good correspondence between the 
zones of low concentrations of Nitrates and the zones of low vulnerability considered as "well protected". Thus, we can consider that this map of spatial distribution of nitrate rate allows validating the maps of vulnerability pollution. However, we note the presence of high nitrate levels in areas of very low and low vulnerability, which confirms that the water tables of N'Djamena city Chad are likely to be threatened locally by the infiltration of pollutants. This situation is quite possible because the notion of vulnerability is not synonymous with current pollution, but rather with a predisposition of these areas to possible contamination, if nothing is undertaken to protect them [40] [41].

At the SI level, we have the best coincidence (100\%) between Nitrate concentrations above $50 \mathrm{mg} / \mathrm{L}$ and the high vulnerability zone. Considering that high nitrate levels are related to anthropogenic pollution not intrinsic pollution (hydrogeological context of the area), we can say that this high coincidence rate shows that the specific SI method better assesses nitrate vulnerability in the case of our study.

\section{Conclusions}

In this study, we chose two methods (GOD and SI) to evaluate the vulnerability to chemical pollution of N'Djamena city Chad. The results show that there is a difference in the number of class's degrees of vulnerability. We obtained four (04) classes of vulnerability for GOD method: the high vulnerability class (38\%), the moderate vulnerability class (29\%), the low vulnerability class $(21 \%)$ and the very low vulnerability class (12\%), against two (02) classes of vulnerability for SI method, namely the classes of low vulnerability (54\%) and moderate (46\%).

The vulnerability mapping of our area study shows that the moderate and high vulnerability areas cover about $67 \%$ and $46 \%$ respectively for GOD and SI. These areas include certain neighborhoods in the center (Am Riguebé, Ridina, Paris-Congo, Moursale), in the east (Gassi) and in the north (Achawayil, Lamadji), as well as all the areas along the Chari and Logone rivers (Sabangali, Farcha, Melezi, Ngueli, Walia, Ndigangali, Ngomba).

The analysis of vulnerability maps (GOD and SI) to groundwater pollution in N'Djamena Chad shows that the vulnerability degree is a function of lithology and permeability of soil; in fact, the risk of pollution of water table of N'Djamena city Chad is greater in the sandy facies than in the clay facies of the unsaturated zone.

Comparing the distribution of nitrates in the groundwater of N'Djamena city Chad and the distribution of vulnerability classes, we note that $91 \%$ of samples with very low nitrate levels ( 0 to $15 \mathrm{mg} / \mathrm{L}$ ) coincide with the very low-to-low vulnerability zones for GOD method. Whereas with the SI method the coincidence rate is $76 \%$ with the low vulnerability zones that, we consider being "well protected" zones. This overlay allows us to say that the maps elaborated reflect the reality on the ground. Apart from that, we also found that the coincidence rate between high nitrate concentrations $(>50 \mathrm{mg} / \mathrm{L})$ and the high vulnerability 
class (100\%). This shows that the specific SI method assesses nitrate vulnerability better than the GOD method. This finding is quite logical because the SI method integrates land use in its formula.

In any case, it seems undeniable that the groundwater of Ndjamena Chad is exposed to the risks of pollution linked to both the hydrogeological context of the aquifer system and to human activities. The risk of nitrate pollution of the city's water is real but variable in places. It is therefore desirable to monitor areas with high nitrate content (an indicator of anthropogenic pollution). Water quality and health are inseparable couple. Such a risk of pollution can pose a long-term problem for public health.

In view of the problem and the real issues related to the risk of vulnerability groundwater in the Ndjamena city Chad, in terms of operational perspectives, it is relevant to develop ( $\mathrm{N}^{\prime}$ djamena Town Hall) an interministerial strategic plan for integrated management of pollution risks on natural resources.

This will not only help to raise awareness among the population on behavioral change in terms of integrated management groundwater resources (IWRM) but will also help to preserve natural resources. It is important not to lose sight of the promotion of rational use of phytosanitary products (fertilizers, pesticides, herbicides, etc.) and of the environment (promotion of hygiene and basic sanitation services) in the areas concerned. Finally, a new research base can be launched through studies of the sanitary and environmental impact of nitrate and other pollutants in anomalous or vulnerable areas.

\section{Conflicts of Interest}

The authors declare no conflicts of interest regarding the publication of this paper.

\section{References}

[1] Ouattara, A., Meite, A., Sally, T., Ouattara, H. and Kati Koulibali, S. (2016) Etude de la qualité des eaux de consommation dans la localité de N'Zianouan s/p de Tiassalé et des quartiers précaires de trois communes de district d'Abidjan (Koumassi, Treichille, Attécoubé). Journal of Applied Biosciences, 102, 9708-9715.

[2] Bosca, C. (2002) Groundwater Law and Administration of Sustainable Development. Mediterranean Magazine Science, Training and Technology, 13-14.

[3] Baghvand, A., Nasrabadi, T., Nabibidhendi, G., Vosoogh, A., Karbassi, A. and Mehradadi, N. (2010) Groundwater Quality Degradation of an Aquifer in Iran Central Desert. Desalination, 260, 264-275. https://doi.org/10.1016/j.desal.2010.02.038

[4] Chaffai, H., Laouar, R., Djabri, L. and Hani, A. (2006) Etude de la vulnérabilité a la pollution des eaux de la nappe alluviale de Skikda: Application de la méthode DRASTIC. Bulletin du Service Géologique National, 17, 63-74.

[5] Djoret, D. (2000) Etude de la recharge de la nappe du Chari Baguirmi par des méthodes chimiques et isotopiques. Thèse de l'Université d'Avignon des pays de Vaucluse (France), $161 \mathrm{p}$.

[6] Kadjangaba, E., Travi, Y. and Puig, J.M. (2006) Influence des rejets d'eaux usées et des décharges sauvages sur la qualité des eaux souterraines de la ville de N’Djaména 
(TCHAD). Journal Algérien des Région Arides, Numéro Spéciale, 101-104.

[7] Kadjangaba, E., Huneau, F., Travi, Y. and Djoret, D. (2017) Recharge and Groundwater Quality of an Alluvial Aquifer: Case of the City of N'djamena (Chad). Journal of Environmental Science and Engineering B, 6, 493-505.

https://doi.org/10.17265/2162-5263/2017.10.001

[8] Kadjangaba, E., Djoret, D., Doumnang, M.J.C., Ndoutamia, G.A. and Mahmout, Y. (2018) Impact des Processus Hydrochimique sur la Qualité des Eaux souterraines de la Ville de N'Djaména-Tchad. European Scientific Journal, 18, 162-177. https://doi.org/10.19044/esj.2018.v14n18p162

[9] Champagne, L. and Chapuis, R.P. (1993) Évaluation de la vulnérabilité à la pollution des formations aquifères de la MRC de Montcalm selon la méthode Drastic. Revue des Sciences et Techniques de P Eau, 26, 76-169.

[10] Elfarrak, H., Hakdaoui, M. and Fikri, A. (2014) Development of Vulnerability through the DRASTIC Method and Geographic Information System (GIS) (Case Groundwater of Berrchid), Morocco. Journal of Geographic Information System, 6, 45-58. https://doi.org/10.4236/jgis.2014.61006

[11] Drias, T. and Toubal, A.C. (2015) Cartographie de la vulnérabilité a la pollution de la nappe alluviale de Tebessa-Morsott (bassin versant de l'Oued Ksob) extrême est algérien. Larhyss Journal, 22, 35-48.

[12] Guillaume, M. and Marie, L. (2015) Étude de la vulnérabilité de l'eau souterraine sur la zone Bécancour (Centre-du-Québec), Géohydro 2011. 7 p.

[13] Vrba, J. and Zaporozec, A. (1994) Guidebook on Mapping Groundwater Vulnerability. IAH International Contributions to Hydrogeology, Vol. 16, FRG, Heise Publication, Hannover, $131 \mathrm{p}$.

[14] Civita, M. (1994) Le carte della vulnerabilit'a degli acquiferi all'inquinamiento: Teoria e pratica [Contamination Vulnerability Mapping of the Aquifer: Theory and Practice]. Quaderni di Tecniche di Protezione Ambientale, Pitagora.

[15] Foster, S. (1987) Fundamental Concepts in Aquifer Vulnerability, Pollution Risk and Protection Strategy. In: Van Duijvenbooden, W. and Van Waegeningh, H., Eds., Vulnerability of Soil and Groundwater to Pollution, TNO Committee on Hydrological Research, The Hague, 69-86.

[16] Ribeiro, L. (2000) Evaluation of an Intrinsic and a Specific Vulnerability Assessment Method.

[17] Gac, J.Y. (1980) Géochimie du bassin du lac-Tchad. Travaux et documents de l'O.R.S.T.O.M. n 1243,251 p.

[18] Olivry, J.C., Chouret, A., Vuillaume, G., Lemoelle, J. and Briquet, J.P. (1996) Hydrologie du lac Tchad. Monographies hydrologique 12. ORSTOM, Paris.

[19] Schneider, J.L. and Wolff, J.P. (1992) Carte géologique et Hydrogéologique au 1/1 500000 de la République du Tchad. Mémoire explicatif. Document BRGM n 209 , Vol. 1, 2, 689 p.

[20] BRGM (1988) Etude de la vulnérabilité des nappes aquifères superficielles de N’Djaména (Tchad) et recommandations pour les aménagements. $90 \mathrm{p}$.

[21] Kushnir, I. (1993) Géologie, ressources minérales et ressources en eau au Tchad. Travaux et documents scientifiques du Tchad. Connaissance du Tchad I. 100 p.

[22] IWAKO (1985) Les ressources en eaux du Tchad. Rapport technique.

[23] BRGM (1967) Etude géochimique des eaux souterraines de l'Afrique de l'Ouest (Tchad), Comité Inter Africain Hydraulique (bureau technique). DAK 67-A62. 
[24] Latifi, S. and Chaab, S. (2017) Assessment and Mapping of the Vulnerability to Pollution of the Groundwater, Using the Both DRASTIC and GOD Methods, in Alluvial Plain of Guelma, Northeast of Algeria. Synthèse: Revue des Sciences et de la Technologie, 34, 48-62.

[25] Murat, V., Paradis, D., Savard, M.M., Nastev, M., Bourque, E., Hamel, A., Lefebvre, R. and Martel, R. (2003) Vulnérabilité à la nappe des aquifères fracturés du Sud-Ouest du Québec: Evaluation par les méthodes DRASTIC et GOD. Ressources naturelles Canada, Commission Géologique, 16. https://doi.org/10.4095/214216

[26] Aller, L., Bennett, T., Lehr, J.H., Petty, R.J. and Hackett, G. (1987) Drastic: A Standardized System for Evaluating Groundwater Pollution Potential Using Hydrogeologic Settings. US-EPA Report 600/2-87-035, 622 p.

[27] Hamza, M.H., Added, A., Frances, A. and Rodriguez, R. (2007) Validité de l'application des méthodes de vulnérabilité DRASTIC, SINTACS et SI à l'étude de la pollution par les nitrates dans la nappe phréatique de Metline-Ras Jebel-Raf Raf (Nord-Est Tunisien). Géoscience, 339, 493-505. https://doi.org/10.1016/j.crte.2007.05.003

[28] Ewodo Mboudou, G., Auguste, O., Bon, A.F., Ntep, F. and Bineli, E. (2016) Apport des méthodes paramétriques DRASTIC, GOD et SI à l'évaluation de la vulnérabilité intrinsèque dans les aquifères du bassin versant de l'Abiergué (région de Yaoundé). Revue CAMES, 4, 67-78.

[29] Corine Land Cover (1993) European Community, Guide Technique. Office des publications Officielles des Communautés Européennes. Série environnement, sécurité nucléaire et protection civile, Bruxelles.

[30] Ake, G.E., Kouadio, B.H., Dongo, K., Dibi, B., Kouame, F.K. and Jean Biemi, J. (2010) Application des méthodes DRASTIC et SI pour l'étude de la vulnérabilité à la pollution par les nitrates $\left(\mathrm{No}_{3-}\right)$ de la nappe de Bonoua (Sud-Est de la Côte d'Ivoire). International Journal of Biological and Chemical Sciences, 4, 1676-1692. https://doi.org/10.4314/ijbcs.v4i5.65557

[31] Allechy, F.B., Lasm, T., Youan, T.M., Yao, K.A.F., Kouakou, O.S., Oka, K.A.R., Baka, D. and De Lasme, O.Z. (2016) Cartographie de la vulnérabilité à la pollution des aquifères du socle Précambrien: Cas de la région d'Oumé (Centre-ouest de la Côte d'Ivoire). European Scientific Journal, 12, 1857-7431. https://doi.org/10.19044/esj.2016.v12n20p374

[32] Boualla, N., Benziane, A. and Ait-Mokhtar, A. (2017) Assessing Vulnerability of Groundwater with GOD Model: A Case Study in Oran Sebkha Basin Algeria. Journal of New Technology and Materials, 7, 18-26. https://doi.org/10.12816/0044031

[33] Achour, M., Hassani, M.I., Mansour, H., Hadj Brahim, A. and Bensaha, H. (2019) Contribution of the GIS to the Establishment of the Intrinsic Map Vulnerability of the Water-Table Aquifer of the Wadi M'zab, Algeria. Journal Algérien des Régions Arides (JARA), 13, 103-113.

[34] Armanuos, A.M., Allam, A. and Negm, A.M. (2020) Assessment of Groundwater Vulnerability to Pollution in Western Nile Delta Aquifer, Egypt. International Water Technology Journal, 10, 18-40.

[35] World Health Organization (2004) Guidelines for Drinking Water Quality, Vol. 1 Recommendations. 3rd Edition, WHO, Geneva. https://www.who.int/water_sanitationhealth/publications/facts2004/en/index.html

[36] Ewodo, M.G., Ombolo, A., Kouame, K.J., Bon, A.F. and Bineli, E. (2015) Evaluation of the Intrinsic Vulnerability of the Mingosso Watershed (Yaounde Region) by Parametric Methods DRASTIC, SI and GOD. International Journal of Innovation and 
Applied Studies, 12, 266-286.

[37] Simboro, A. (2015) Gestion quantitative et qualitative des ressources en eau dans la plaine alluviale de Karfiguéla à l'aide d'un SIG: Etude de la recharge induite de la nappe et sa vulnérabilité à la pollution, Institut International d'Ingénierie (2iE) Burkina Faso. 71 p.

[38] Jourda, J.P., Saley, M.B., Djagoua, E.V., Kouame, K.J., Biemi, J. and Razack, M. (2006) Utilisation des données ETM+ de Landsat et d'un SIG pour l'évaluation du potentiel en eau souterraine dans le milieu fissuré précambrien de la région de Korhogo (nord de la Côte d'Ivoire): Approche par analyse multicritère et test de validation. Revue de Télédétection, 5, 339-357.

[39] Hamit, A., Lucas, K., Sakamou, I.E. and Adoua, N.K. (2017) Assessment of the Vulnerability of Groundwater to Pollution in N'Djamena (Chad) Using the DRASTIC Index Method. International Journal of Current Research, 9, 58911-58919.

[40] Kouame, K.J. (2007) Contribution à la Gestion Intégrée des Ressources en Eaux (GIRE) du District d'Abidjan (Sud de la Côte d'Ivoire): Outils d'aide à la décision pour la prévention et la protection des eaux souterraines contre la pollution. Thèse de Doctorat, Université de Cocody, Abidjan, 250.

[41] Koudou, A., Assoma, T.V., Adiaffi, B., Youan, T.A.M., Saley, M.B. and Kouame, K.F. (2017) Assessment of Fracturing Influence in the Touchness to the Aquifers Pollution of the Contact Zone between Bedrock and Sedimentary Basin in the Southeast of Côte D’ivoire. Larhyss Journal, 32, 71-91. 